\title{
TIMON OF ATHENS, FOOD TRANSFORMATIONS, AND THE WORLD AS CONFECTIONARY
}

\author{
Simon C. Estok \\ Sichuan University \\ Sungkyunkwan University \\ estok@skku.edu
}

\begin{abstract}
In the transformation of early modern English food sources from the local to the international are a wide range of questions about the global-sourcing/local-demand conflict that was developing in Shakespeare's time and continues today. Shakespeare's food reveals the complexities of a network of global and local actors and transformations. As a performance, Timon of Athens potentially arouses sometimes intense visceral responses (ones that are peculiarly resonant with contemporary audiences) to Timon's dream that the world is his confectionary. One of the results of performing the transformation of food from the local to the global (the play's explicit representation of the world as Timon's unsustainable confectionary) is that we are better able to see and understand ecological collapse: while anthropogenic ecological collapses in early modern times were relatively isolated, today's collapses are more properly understood as global. We witness the transformative and deterritorializing potentials of food, even while such transformations are in the service of a deeply nationalist agenda that is troubling and unsustainable in its rejection of global connectedness. Performance is vital for excavating the layers and implications of food transformations and potentials in Timon of Athens, a play deeply relevant to food transformation debates current in the $21^{\text {st }}$ century.
\end{abstract}

\section{Keywords}

early modern food; global-sourcing/local-demand; performance; sustainable food sourcing; Timon of Athens 


\section{About the Author}

Simon C. Estok currently holds the award of Foreign Expert of the Double First Class Discipline Cluster (2018-2021) at Sichuan University and is Full Professor and Senior Research Fellow at Sungkyunkwan University (South Korea's first and oldest university). Dr. Estok teaches literary theory, ecocriticism, and Shakespearean literature. His award-winning book Ecocriticism and Shakespeare: Reading Ecophobia appeared in 2011 (Palgrave Macmillan, reprinted 2014), and he is co-editor of three books: Landscape, Seascape, and the Eco-Spatial Imagination (Routledge, 2016), International Perspectives in Feminist Ecocriticism (Routledge, 2013), and East Asian Ecocriticisms (Macmillan, 2013). His latest book is the much anticipated The Ecophobia Hypothesis (Routledge, 2018). Estok has published extensively on ecocriticism and Shakespeare in journals such as PMLA, Mosaic, Configurations, English Studies in Canada, and others.

Kritika Kultura 33/34 (2019/2020): 668-683

(c) Ateneo de Manila University

<http://journals.ateneo.edu/ojs/kk/> 
Food is an unusually transformative material on the Shakespearean stage. Embedded in Shakespeare's food-a material on stage that in performance evokes sometimes intense visceral responses-are the complexities of a network of global and local actors and transformations. As performance (which is what all of Shakespeare's plays were intended as), the drama speaks very differently than the literature, the written text. Shakespeare's food embodies the inverse relationship between nationalism on the one hand and the increasingly global reach of the British imperial appetite on the other, a conflict that continues to press upon the present. To engage with the questions raised by the global-sourcing/localdemand conflict of Shakespeare's food through performance-and to do so from geographically, temporally, and ideologically situated positions-exposes the radically transformative and deterritorializing potentials embedded in food.

Within Shakespeare's food are the values of the time and place of early modern England, but no less (and very differently) of twenty-first century Seoul, Vancouver, and Manila. The English physical text (with all of its squabbles) ${ }^{1}$ is virtually the same everywhere. The performance, like the translation, is a deeply malleable and transformable (and transformative) thing. If plays begin where the original texts leave off (May, "Greening" 85), then what use can Shakespeare's food perform today? Precisely how can contemporary productions highlight the unsustainability of the affect these plays produce? How can we take seriously and work with Sylvan Goldberg's assertion that "as an affective ecocriticism emerges, we do well to consider not just what sustainability feels like, but what feelings are sustainable" $(56)$ ?

To answer such a question about a performance is an entirely different matter than it would be with a written text. Shakespeare in performance is not the same spatiotemporal experience as Shakespeare in literature, obviously, and it "can broach the question of an inside/outside boundary in many ways" (Bottoms, Franks, and Kramer 3). Affect theory, therefore, is important here: "the difference attention to affect makes is that it forces a recognition of the importance of qualities and intangible objects" (Davidson, Park, and Shields 319). As the performance is different from the text, so too doing an ecocritical reading of a play as literature is a very different thing than doing an ecocritical analysis of the performance of one, but "the theatre sector has been "comparatively slow to pick up the ecological baton" (Bottoms 121). Ecocriticism itself has been slow to pick up the ecological baton in theorizing about "ways in which Shakespeare in performance can foster ecological consciousness and change" (Martin, "Towards Ecocriticism in Performance"), and there are clear possibilities for ecocritical investigations of the local/global tensions embodied in Shakespeare's food transformations. Ursula Heise takes a stand on the debate that has grown out of these tensions and argues for the need 
to envision how ecologically based advocacy on behalf of the nonhuman world as well as on behalf of greater socioenvironmental justice might be formulated in terms that are premised no longer primarily on ties to local places but on ties to territories and systems that are understood to encompass the planet as a whole. (10)

For a playwright with a dramatic global appeal such as Shakespeare's, the ecological implications of theatrical performances of food-performances that "encompass the planet"-is a topic to which ecocritical attention is long overdue.

Performance theorist Theresa J. May makes a strong case for extending ecocritical analysis to theater:

When the ecocritical view can expand its scope to include the issues of race, class, gender, geographic situated-ness, and white power and privilege, then theatre-which has always been a force for activism as well as the dissemination of hegemonic mythsappears ripe for analysis. Indeed, theatre's inherent communality makes it an ideal site for examining the habits of mind that perpetuate unjust and unsustainable paradigms, and/or precipitate cultural transformation. (“Greening” 87)

It is not entirely clear to me to which "habits of mind" May refers, but it is reasonable to suggest that doing ecocriticism with performances of Timon of Athens ${ }^{2}$ must include analysis of audience affect when the plays actively present ecophobic visions.

Sylvan Goldberg's modest forays into affect theory bear importantly on this discussion and on understanding the intersections of performance theory, affect theory, and the environmental contours and implications of food in the drama. As Goldberg describes it, "the affective register of our bodies offers a catalogue of encounters through which to understand the interpenetration of the human and nonhuman worlds" (55). "Heaved into embodied life on a physical stage before a fleshand-blood audience that the players knew and strove to please," if I may borrow the words of Theresa J. May again ("Review" 140), Shakespeare implicates his audiences in a drama of food that cannot but be both local and global. The obviousness of the global nature of the material foodstuffs circulating in Shakespeare's time makes extended commentary here unnecessary: this globality is neither unique to Shakespeare's time nor particularly revealing in any analytical way. Indeed, as food theorist Jennifer Clapp has explained, "[t]hroughout history world food markets have had an international dimension to them" (8). But given the centrality of food (and the ways it is transformed) to cultural self-definition the world over, what exactly does looking at Shakespeare from a twenty-first century Seoul or Manila classroom entail? Apart from the obvious point that non-appropriative 
performance produces an audience that participates in an essentializing sweep of the local (i.e., Shakespeare is over there and back then), there are other possibilities.

Working in Seoul, I engage with different histories and possibilities for reading Shakespeare than I would in Western Canada or West Africa. The history of Shakespeare in Korea over the past two decades has been attuned to presentist and localist matters of the performances themselves. According to Hyon-u Lee, Korean directors "found Shakespeare to be one of the best methodologies to satisfy the ambivalent desire of Korean people in the 1990s to acquire something global as well as something traditional" (42) and local. Kathy Foley, in her review of a collection entitled Glocalizing Shakespeare in Korea and Beyond, observes that " $t$ ] he return to the local was certainly motivated in part by a desire to reject the American influences on Korean politics and culture that had dominated from the Korean War until the ouster of dictatorial rule: mask dance and drumming became popular in the theater from the 1980 s as a sign of a growing embrace of postcolonial independence" (391). Yet, the transformations of Shakespeare are clearly in the service of a reiteration of rigid boundaries, and these are not only national: they are also disciplinary.

In my professional "here," there are as of yet no Shakespeareans in ASLEKorea, ${ }^{3}$ except me. Similarly, I am the only ecocritic (or ASLE member) in the Shakespeare Association of Korea. Rigidity, compartmentalization, and a kind of competitiveness that often results in a lack of scholarly cooperation still characterize Korean academia. Such is my professional "here," one, however, in which I remain a postcolonial foreigner, unassimilated, racially noticeable, but unquestionably benefitting from the colonial history of which Shakespeare is a part.

Korea first encountered Shakespeare under colonization not by the British but by the Japanese (Moran 200). In a version of the "empire writes back" theme, Dara Kaye has argued compellingly that "global Shakespeare' is no longer evangelized or borrowed in one direction from authoritative English texts into foreign-language performances but is instead a circulatory ecosystem, with influences intersecting and exchanging between East and West." Kaye's work is one of a handful of pieces on "Shakespeare and Korea," a relatively small collection compared with the work done on Shakespeare and Japan. And ecocritical fingers, have not scratched very deeply into Shakespeare in Korea either.

When I teach Timon of Athens in Korea, I begin with a discussion of Carrefour, one of the largest hypermarkets (supermarket and department stores combined), and how it was forced to sell all of its sixteen stores in Korea because of a food fight in one of these stores. The manager of the meat department in one of the Seoul stores lied about the origin of the beef, claiming it was from Korea rather than Australia. 
The nominally transformed beef apparently did not taste any different (despite a very long tradition of Koreans praising the taste of "Hanwoo" over foreign beef), and it took forensic and DNA tests to make the case. Hanwoo is triple the price of Australian and American beef. The deceptive transformation of Australian cow flesh into Hanwoo allowed the store to charge a lot more for the meat. The reason Hanwoo is so expensive is that there is relatively little land in Korea, and the land simply cannot support the country's growing demand for beef (used in, among other foods, the famous Korean bulgogi). It is here, through a discussion about the transformative potentials of desires that go beyond local carrying capacities that I move into Timon in the classroom.

I begin with Timon's advice about feeding upon the stuff offered by nature:

Your greatest want is, you want much of meat. Why should you want? Behold, the earth hath roots. Within this mile break forth a hundred springs. The oaks bear mast, the briars scarlet hips. The bounteous housewife nature on each bush lays her full mess before you. Want? Why want? (4.3.418-23)

This is a remarkable ethically vegetarian set of sentiments! Timon of Athens repeatedly_sometimes blatantly-links meat and environment. David Goldstein's question about what it means "to eat, and to write about eating, in Renaissance England" (3) must begin with the irony of the international pathways that lead to national self-definition. Feeding Korea's appetite for bulgogi with Australian beef (or for kimchi made in China with China-grown cabbage and spices) echoes this dynamic. When the local coffers run out, the world itself is transformed. It becomes a confectionary.

Timon certainly is a person of the Renaissance and sees the world as belonging to himself for his own consumption: "myself, who had the world as my confectionary" (4.3.259-6o), have lost everything, he complains. He ought to have thought about his unsustainable lifestyle earlier: in this, he seems almost an allegorical critique of contemporary humanity and its conspicuous consumption. Relying on a framework that presumes exemption of the natural world from ethical consideration (an exemption connected with ecophobia), early modern English food sources, as I have already mentioned, were noticeably transforming from the local to the international, a global confectionary. Joan Thirsk pointed out in a 1999 essay introducing a Folger exhibition on food in Shakespeare's England that the transformation of the local to a global supermarket is one that began in Shakespeare's time: "sixteenth-century English [people] were familiar with a far greater range of foodstuffs procured locally than we are today... [and] a large portion of the population lived in the countryside, had access to wild plants, animals, and birds in the fields and woods, and ate mostly the foods produced in their own locality" (14). Things were changing, and "people 
were also traveling further afield than hitherto; more of them traveled in Europe, some went to the Far East, and others ventured across the Atlantic" (13). Mary Anne Caton explains that in Shakespeare's day, English cuisine was transforming, and it "combined the flavors of imported spices like cinnamon, nutmeg, pepper, and cloves with herbs and acidic binders or liaisons like verjuice (liquid from pressed unripe apples or grapes) or vinegar. Spices were imported from the Spice Islands in Malaysia by Portuguese and Venetian merchants" (10). Caton also reminds us that "hot liquids-chocolate, tea, and coffee-began to change how the elite socialized" (10). This, then, is the context in which Timon's "the world [i]s my confectionary" comment is nestled. And in post-"Asian financial crisis" Korea ${ }^{4}$ (where deals for the US\$ 58 billion bailout included unprecedented foreign trade requirements), bourgeoning foreign markets and goods have poignant and deeply ambivalent significance, at times producing an insular xenophobia, ethnocentric racism, and topophilia, and at other times a kind of cultural cringe and repudiation of the local that is politically disconcerting. This nationalism and its culinary implications bears interesting isomorphic resonances with Shakespeare's historical moment.

Involved not only with the sense of self-entitlement attendant on Britain's growing nationalism and its increasingly global appetite, a nonchalance toward nature is fundamental to the ethics of waste in the play and to the notions about an endless resilience of the (unacknowledged) natural world to provide more bounty. It is not just the imaging of Athens as hostile, as "a forest of beasts" (4.3.348)-like Titus's description of Rome as "a wilderness of tigers" (Titus 3.1.54); it is not just the conceptual violence against nature rooted in both dissociation from and contempt toward Nature that this play registers: it is also the irreversible effects of the sheer nonchalance toward Nature, the complacency about Nature's material availability, and the general lack of appreciation for what Nature provides that defines the contours of this play's ecophobia.

Teaching this material in Seoul, I get into discussions about food in Korea-a sensitive topic for several reasons. Food waste in South Korea, once an indicator of freedom from the austerity of colonial and wartime pasts, is bound up with matters of history, national identity, power, pride, resistance, and many other things. The rapid economic development of Korea-what has been called "The Miracle on the Han" (Han Gang oui Geechock, 한강의 기적)—has produced a sense of freedom to indulge, a sense of freedom to spend and freedom to waste: it is the kind of conspicuous consumption and conspicuous wastage that perhaps characterizes all newly rich economies. A great many reports in the first decade of the twenty-first century report on the continuing problem of excessive portions and subsequent wastage in restaurants-and a resulting solution to this problem of waste has been "the re-use of left-over food in [Korean] restaurants" (Schwartzman). Angry reports 
of the unhygienic and unhealthful recycling of waste food continue to appear in Korean media.

Switch back to Shakespeare and how "proliferating reports of newly discovered oceans, terrains, climates, peoples, animals, and plants" (Martin, Shakespeare and Ecology 5) were destabilizing and transforming the epistemological boundaries, to use Randall Martin's terms, of Shakespeare's England and of the fact that "three or four times as much coal was probably produced in Great Britain as in the whole of continental Europe" combined (Carus-Wilson 98)- "much of it burned in London" (Hiltner 429) - and performances of Timon in Seoul take on a very different affect in Seoul than in Kitsilano. The "center of the universe" thinking of the play that pits the local against the global, the present against the future, and the human against everything else resonates much differently for a country that industrialized within a span of twenty or thirty years than for one that started much sooner and took much longer. Funding the extravagance of the individualist nation Timon embodies was "the shift to coal," which Martin explains, "signalled emerging trade-offs that have become a part of our global reality: private comfort versus public health; personal prosperity versus environmental degradation; social progress versus planetary risk" (Shakespeare and Ecology 3). England's use of sea coals signals something else: the tension between the local and the nonlocal and also, by implication, between the individual and the community.

While the focus on the individual that characterizes Euro-American culture is strong, in Korea, as in much of Asia, there is a much stronger concern for community. This registers in the use of the pronoun "oori" (우리, "our") before so many nouns in Korean-our country (우리나라, oori nara), our bank (우리은행, oori eunheng, known internationally as "Woori Bank"), and so on. When a professor's parent dies, each member of the department contributes 100,00o won for the funeral. When there is a wedding, each invited guest makes a similar contribution. It is unseemly for people to suffer alone. It is also very unusual for people to eat alone. Historically, it was rare to see people eating alone in restaurants in Korea. Timon could not happen in Korea. ${ }^{5}$ Yet, the opening of Korea to Free Trade Agreements has threatened both the sense of community and the trust in food safety in the nation. My students told me when I last taught Timon that despite the ban on the cultivation of any genetically modified (GM) crops in Korea (a country which is, nevertheless, "now the world's second biggest importer of GM crops"), ${ }^{6}$ GMO pollution has become an irreversible problem. Fields everywhere have rogue GM plants mixed among the crops. These transformations cannot easily be undone. How could this have happened?

I wonder aloud in the class what is going on with meat in Timon and what other ecocritical insights we might offer in Seoul classrooms, situated differently as they 
are. ${ }^{7}$ One thing I mention to my classes in Korea is that it is perhaps reasonable to suggest that Timon's defense of a vegetable diet sounds very contemporary, much as a vegetarian these days (in North America and in Korea) responds to a querulous carnivore's "why don't you eat meat?" or "When did you become a vegetarian?" Another thing I mention in my classes is that the Banditti's response to Timon's question about "why want" endorses carnivorism as the natural human way and meatless diets as other, different, and bestial: "we cannot live on grass, on berries, water, / As beasts and birds and fishes" (4.3.422-3). This comment alone supports Joan Fitzpatrick's claim that meatless diets were regarded with suspicion in Shakespeare's England in ways that such diets are not today; but, as I have recently argued in "Queerly Green" in Ecological Approaches to Early Modern English Texts, there is much more to it than that.

For instance, it is certain that in Shakespeare, meatless diets (and perhaps therefore the local) seem to point toward some kind of weakness, to matters of class, and to matters of sexuality. In 2 Henry VI, Jack Cade does not fare so well, and when the weak king himself expresses sympathy for animals, his sympathies seem also symptomatic of weakness. Gabriel Egan may mock and suggest crude misreadings are at play, but he is in no position to make such comments. ${ }^{8}$ The fact is that Timon is weakened when he moves away from carnivorism, and attendant on his move away from meat are transformations: giving up meat results in disempowerment that seems to reveal "the powerful links between meat-eating, masculinity, and virility in western societies" that Annie Potts and Jovian Parry discuss in their fascinating "Vegan Sexuality: Challenging Heteronormative Masculinity through Meat-free Sex."

The material implications of early modern food on twenty-first-century stages obviously will differ depending on location. Shakespeare's food will evoke very different affective responses in a country such as India, where more than $30 \%$ of the population is vegetarian than in South Korea, where only about $1 \%$ of the population is vegetarian (see Kim), or in Canada, where, according to one source (see Pippus), a whopping 33\% claim to be vegetarian. Work on material implications of transformational objects and their relations is just beginning in ecocriticism, and it is deeply complex work, with an enormous amount waiting to be done.

Increasing attention within ecocriticism (particularly from the work in what has come to be known as "material ecocriticism") stresses the agential capacity of nonhuman animals and things. I am skeptical both about how new this version of materialism is and about the limits of theorizing about agency. Suggesting that climate (or non-sentient nature in general) is capable of volition, it seems, is a mistake that points toward anthropomorphism. This said, however, the agency of nature in Timon is not to be ignored. The ecosystemic nelsoning of Timon leaves 
him little food but rocks and roots after his unsustainable extravagance. Far from understanding the "systemic sense of planet" (Heise 56) from which his bounty came, Timon squanders all and remains stuck in a desolate local space, cut off from global citizenship, reduced, hopeless, suicidal. Food transformations are an integral part of globalization, ${ }^{10}$ and reading the performance of food in Timon must take this into account.

Theater is about physical encounters and witnessings that have bodily, intellectual, and emotional impacts. Theater naturally lends itself to analysis through affect theory, and since "[e]cocriticism, like feminism, post-colonial or multi-cultural theory, addresses injustices felt in the body-the body of experience, of community, of land" (May, "Beyond Bambi" 86), combining affect theory, ecocriticism, and performance theory is reasonable. Moreover, it is reasonable to expect that at least one result of so doing will be that the 2019 audience of Shakespeare on the Beach in Vancouver is going to be a very different one than at, say, The Rose, The Globe, The Swan, or The Curtain of hundreds of years ago and that the ecophobic affect of the early modern stage is simply not sustainable.

Early modern English food sources were changing from the local to the international, and engaging with the questions posed by the global-sourcing/localdemand conflict shows, as I have demonstrated, how radically transformative the potentials embedded in food are. Green performances are important in excavating the layers of these tranformations and potentials. Green Shakespeares are obviously possible in performance, ${ }^{11}$ but what will be the affective result? To what end will these performances strive? One of the results of performing the transformation of food from local to global, from the play's explicit representation of the world as Timon's unsustainable confectionary, is that we are better able to see and understand ecological collapse: while anthropogenic ecological collapses in early modern times were relatively isolated, today's collapses are more properly understood as global. We can talk about food in Shakespeare from here and now (when "here" is not always singular), and so doing allows for understandings of the transformative and deterritorializing potentials of food, even while such transformations are in the service of a deeply nationalist agenda. Timon's food provokes questions about sustainability, questions with which contemporary audiences are intimately familiar. It also reflects a troubling and unsustainable nationalism, one that rejects global connectedness. In different geographical and temporal spaces, food transformations are embedded in a complex and nuanced planetary web, one whose stability is fragile, both in Timon of Athens and in our current world. 


\section{Acknowledgement}

This article was funded by the double-first class discipline cluster "The Chinese Language and Literature and the Global Dissemination of Chinese Culture," Sichuan University, China. 


\section{Notes}

1. Hamlet's flesh ("O, that this too too (solid/sallied/sullied\} flesh would melt...") is perhaps the most famous of these.

2. All references to Shakespeare use The Riverside Shakespeare, second edition, edited by G. Blakemore Evans and J. J. M. Tobin, Houghton Mifflin, 1997.

3. ASLE began in 1992 and rapidly evolved away from its largely Americanist perspective to develop into organization with global affiliates. Today, there are affiliates in Canada, Japan, Australia/New Zealand, Europe, Taiwan, Korea, Pakistan, India, the UK and Ireland, and the ASEAN region.

4. Things are changing, and it is becoming increasingly common to see "hanjok"-a term from the words "han" (한) and "jok" (족), meaning "alone" and "tribe" respectively-in restaurants and coffee shops.

5. The East Asian financial crisis is misnominally referred to as "the IMF Crisis" in Korea.

6. See Benson.

7. To set things in context, it is important to note that an important part of South Korea's development has had to do with meat consumption. Gone are the days when the best meat to be found was Spam, distributed by the US Army in the Korean War (though ironically, this junk-and Spam has become synonymous with junk-maintains a high status in Korea). While Spam has not lost its status as food, real meat has become more plentiful. And meat, as a source of food, is horrendously wasteful as I explained in an article a couple of years ago, it is "difficult to take seriously...the ecocritic who theorizes brilliantly on a stomach full of roast beef on rye" ("Theorizing" 217), and "most simply put, someone who regularly eats factory-farmed animal products cannot call himself an environmentalist without divorcing that word from its meaning" (Foer 59). A recent article in Time notes that "Livestock production-which includes meat, milk and eggs-contributes $40 \%$ of global agricultural gross domestic product . . . and uses one-third of the world's fresh water. There may be no other single human activity that has a bigger impact on the planet than the raising of livestock" (Walsh). According to one source, "South Koreans are consuming more meat than ever while their annual intake of rice continues to set record lows every year"-meat consumption "up nearly four times" since 1980 (see “S. Korea's," Works Cited). An official at the Korean Ministry of Agriculture states that " $[\mathrm{t}]$ he country's meat consumption has jumped greatly as people's eating habits are becoming more and more Westernized” (see "S. Korea's," Works Cited). Yet, this explanation lacks empirical evidence, and, indeed, statistics may show something quite different. Western fast-food chains and domestic Western-style restaurants account for a fraction of the total meat consumption in Korea, and despite xenophobic fears of a Western culinary invasion, meat consumption is sky-rocketing in Korea for domestic reasons. Korea has more money than ever before (currently \#11 on the annual disposable income index). This is after a half century of colonial occupation and

Kritika Kultura 33/34 (2019/2020): 678-683

(C) Ateneo de Manila University

<http://journals.ateneo.edu/ojs/kk/> 
then a crippling war (no peace treaty yet), and then decades of dictatorship and privation.

8. It is difficult to take Egan's self-identified ecocriticism seriously, but it is necessary, unfortunately, to respond. In sharp contrast to real scholarship in ecocritical Shakespeares stands Egan's Shakespeare and Ecocritical Theory, a factually flawed, poorly organized, and uninformative volley into ecocriticism. Egan seems sincerely to believe that all Shakespearean ecocriticism is "post-2006" (13). Proper research reveals, however, that the first published work clearly identifying itself as Shakespearean ecocriticism appears in 1998. Egan also discusses, ridiculously, how "flies might grieve" (102). Most of us, however, know that lacking the brain necessary for such functions, flies cannot grieve. Egan goes on to claim that Shakespeare's first audiences might have thought that flies live in families (102), but he does not provide any empirical evidence for such a comment. Egan's book rambles and seems simply not to know where it is going. Large chunks are not about or related to Shakespeare at all, and nowhere is there any engagement with the debates that inform ecocritical theory. For Egan to have an entire chapter on animals without a single mention therein of the brilliant and influential work of Bruce Boehrer or Karen Raber is simply inexplicable. Like his first book on the topic, this one fails to deal with ecocriticism on any level. No serious ecocritic will gain anything from this book. To call what Egan does "ecocriticism" is to divorce the word from its meaning.

One has to wonder, moreover, to whom Egan thinks he is writing when he explains that "almost all human beings have cells containing the genes from two parents in a random 50/50 per cent mixture: half from the mother and half from the father" (95). Does Egan genuinely believe that he is offering ecocritical readings? At one point he compares the evolution of ants with the development of computers:

It took evolution millions of years to come up with the ants' algorithm by the utterly wasteful process of blindly trying every possible solution and throwing away (by natural selection) all those that did not work. By contrast, once humans put their minds to the problem they homed in on the solution in a few years and then broadcast the solution in the form of technical papers for all to copy. (125)

Is this ecocriticism? Ecocritical theory? Shakespeare and ecocritical theory? If so, exactly how so?

Egan's rah-rah celebration of digital communications seems similarly to lack ecocritical mindfulness: in concluding the entire book, he drones on with unenlightened and uncritical enthusiasm about how the internet is useful for environmental activism, about how "communications technology has enabled green activism" (158), and, in so doing, seems blissfully unaware that by 2009 , "the server farms that allow the internet to operate and that provide cloud-based digital computing had surpassed the airline industry in terms of the amount of 
carbon dioxide released into the earth's atmosphere" (Rust, Monani, and Cubitt 3). Again, one wonders where exactly the "ecocritical theory" (promised in the title) is to be found in this book. This book-like his book from a decade earlier, still peddling outdated material and still pedalling to catch up-is an embarrassment to read. As a primer for an elementary school readership, Egan's book might work; for anyone beyond such a readership, however, the book has no value.

9. See Potts and Parry 53-72.

10. One of the largest demonstrations ever to hit the streets of Seoul happened on June 6, 2008, with a million people protesting against the resumption of imports of American beef to Korea. Part of a broader protest against the pending US/ Korea FTA, the protests against beef imports registered concerns both about food safety (particularly, concerns about BSE in American beef) and about cultural/ national autonomy.

11. Performance theory may have been slow to pick up the ecocritical baton, but so what? Shakespeare studies was slow to pick up the baton too. I published the first article that used "ecocriticism" and "Shakespeare" together (a blasphemy in 1998), and there were no warm welcomes by either Shakespeareans or ecocritics. Well, both sides got over it, and Green Shakespeare is a thriving business. Green performances of Shakespeare will be too.

Kritika Kultura 33/34 (2019/2020): 680-683 


\section{Works Cited}

Benson, Jonathan. "GMOs Found Growing in South Korea, Despite National Ban." Natural News, 26 Jan. 2015, http://www.naturalnews.com/o48631_GMOs_genetic_pollution_ South_Korea.html. Accessed 12 June 2016.

Bottoms, Stephen. "Review of Theatre Ecology." RiDE (Research in Drama Education): The Journal of Applied Theatre and Performance, vol. 15, no. 1, 2010, pp. 121-26.

Bottoms, Stephen, Aaron Franks, and Paula Kramer. "Editorial: On Ecology." Performance Research, vol. 17, no. 4, 2012, pp. 1-4.

Carus-Wilson, Eleanora M. Essays in Economic History. E. Arnold, 1954.

Caton, Mary Anne. "Introduction: 'For Profit and Pleasure': Changes in Food and Farming." Fooles and Fricassees: Food in Shakespeare's England, edited by Mary Anne Caton and Joan Thirsk. Folger Shakespeare Library, 1999, pp. 9-11.

Clapp, Jennifer. Food. Polity, 2012.

Davidson, Tonya K., Ondine Park, and Rob Shields. “Introduction.” Ecologies of Affect: Placing Nostalgia, Desire, and Hope, edited by Tonya K. Davidson, Ondine Park, and Rob Shields. Wilfred Laurier UP, 2011, pp. 1-15.

Egan, Gabriel. Shakespeare and Ecocritical Theory. Bloomsbury, 2015.

Estok, Simon C. "Postcolonial Ecocriticism Afterword: Reckoning with Irreversibilities in Biotic and Political Ecologies." Ariel: A Review of International Literature (Special Issue: Post-Colonial Ecocriticism), vol. 43, no. 4, Fall 2013, pp. 219-232.

--. "Queerly Green: From Meaty to Meatless Days and Nights in Timon of Athens." Ecological Approaches to Early Modern English Texts: A Field Guide to Reading and Teaching, edited by Jennifer Munroe, Edward J. Geisweidt, and Lynne Bruckner, Ashgate, 2015, pp. 91-8.

-.. "Reading Ecoambiguity." Ecozon@: European Journal of Literature, Culture and Environment, vol. 4, no. 1, Spring 2013, pp. 130-8.

-.. "Theorizing in a Space of Ambivalent Openness: Ecocriticism and Ecophobia." ISLE: Interdisciplinary Studies in Literature and Environment, vol. 16, no. 2, Spring 2009, pp. 203-25.

Fitzpatrick, Joan. Food in Shakespeare: Early Modern Dietaries and the Plays. Ashgate, 2007.

Foer, Jonathan Safran. Eating Animals. Little and Brown, 2009.

Foley, Kathy. "Review of Glocalizing Shakespeare in Korea and Beyond." Asian Theatre Journal, vol. 27, no. 2, Fall 2010, pp. 390-3.

Goldberg, Sylvan. “'What is it about You ... That So Irritates Me?': Northern Exposure's Sustainable Feeling." New International Voices in Ecocriticism, edited by Serpil Oppermann, Lexington, 2015, pp. 55-70.

Goldstein, David. Eating and Ethics in Shakespeare's England. Cambridge UP, 2013.

Heise, Ursula. Sense of Place, Sense of Planet: The Environmental Imagination of the Global. Oxford UP, 2008. 
Hiltner, Ken. "Renaissance Literature and our Contemporary Attitude toward Global Warming." ISLE: Interdisciplinary Studies in Literature and Environment, vol. 16, no. 3, 2009, pp. 429-41.

Kaori, Kobayashi. "Going Beyond the Boundaries: The Cultural Translatability of Asian Shakespeares." Glocalizing Shakespeare in Korea and Beyond, edited by Lee Hyon-u, Dongin, pp. 243-59.

Kaye, Dara. "Inherently Indirect': Two Recent Korean Adaptations of Shakespeare." Pacific Ancient and Modern Language Association Conference. Seattle, WA. 20 Oct. 2012.

Kim, Bo-eun. "Embracing Vegetarianism." Korea Times, 1 Apr. 2015, http://www. koreatimes.co.kr/www/news/nation/2016/06/654_176353.html. Accessed 10 July 2016.

Lee, Hyon-u. "Populist Shakespeare in Democratized South Korea." Glocalizing Shakespeare in Korea and Beyond, edited by Lee Hyon-u, Dongin, pp. 29-44.

Martin, Randall. CFP. “Towards Ecocriticism in Performance.” June 2015, http://www. academia.edu/11963212/Sexuality_from_Below_Shakespeare_Association_of_America_ New_Orleans_March_2016. Accessed 1 July 2016.

-.. Shakespeare and Ecology. Oxford UP, 2015.

May, Theresa J. "Beyond Bambi: Toward a Dangerous Ecocriticism in Theatre Studies." Theatre Topics, vol. 17, no. 2, September 2007, pp. 95-110.

--. "Greening the Theatre: Taking Ecocriticism from Page to Stage." Interdisciplinary Literary Studies: A Journal of Criticism and Theory, vol. 7, no. 1, Fall 2005, pp. 84-103.

--. "Review of Ecocriticism and Shakespeare: Reading Ecophobia." Theatre History Studies, vol. 34, 2015, pp. 137-40.

Moran, Kim. “The Stages 'Occupied by Shakespeare': Intercultural Performances and the Search for 'Korean-ness' in Postcolonial Korea." Re-Playing Shakespeare in Asia, edited by Poonam Trivedi and Minami Ryuta, Routledge, 2010, pp. 200-220.

Pippus, Anna. "Almost 12 Million Canadians Now Vegetarian Or Trying to Eat Less Meat!" Vancouver Humane Society, 1 June 2015, http://www.vancouverhumanesociety.bc.ca/ almost-12-million-canadians-now-vegetarian-or-trying-to-eat-less-meat/. Accessed 10 July 2016.

Potts, Annie, and Jovian Parry. "Vegan Sexuality: Challenging Heteronormative Masculinity through Meat-free Sex." Feminism Psychology, vol. 20, no. 1, February 2010, pp. 53-72.

Rust, Stephen, Salma Monani, and Sean Cubitt. "Introduction: Ecologies of Media." Ecomedia: Key Issues, edited by Stephen Rust, Salma Monani, and Sean Cubitt, Routledge, 2105, pp. 2-10.

"S. Korea's per capita meat consumption jumps nearly fourfold in 3 decades." Yonhap News, 13 Apr. 2015, http://english.yonhapnews.co.kr/business/2015/04/13/69/05010000ooAE N2015041300130032oF.html. Accessed 21 July 21, 2016.

Schwartzman, Nathan. "Korean Restaurants Still Recycle Leftovers." Asian Correspondent, 4 June 2011, http://asiancorrespondent.com/2011/o6/korean-restaurants-still-recycleleft-overs/. Accessed 7 July 2016.

Shakespeare, William. The Riverside Shakespeare. Second edition, edited by G. Blakemore Evans and J. J. M. Tobin, Houghton Mifflin, 1997. 
Thirsk, Joan. "Food in Shakespeare's England." Fooles and Fricassees: Food in Shakespeare's England, edited by Mary Anne Caton and Joan Thirsk, Folger Shakespeare Library, 1999, pp. 13-25.

Walsh, Bryan. "The Triple Whopper Environmental Impact of Global Meat Production.” Time, 16 Dec. 2013, http://science.time.com/2013/12/16/the-triple-whopperenvironmental-impact-of-global-meat-production/. Accessed 12 Sept. 2016. 